\title{
Integration of subsidence and sequence stratigraphic analyses in the Cretaceous carbonate platforms of the Prebetic (Jumilla-Yecla Region), Spain
}

\author{
Lorenzo Vilas*, Javier Martín-Chivelet, Consuelo Arias \\ Departamento de Estratigrafía, Instituto de Geología Económica (CSIC-UCM), Facultad de CC. Geológicas, \\ Universidad Complutense, 28040 Madrid, Spain
}

\begin{abstract}
An integrated analysis of subsidence and sequence stratigraphy of the Cretaceous successions of the JumillaYecla Region (Betics, SE Spain) is supported by abundant stratigraphical, sedimentological and palaeontological data, with the aim to document and explain the accommodation changes that controlled the evolution and architecture of the carbonate platforms generated during that time on the southern continental margin of Iberia. The Cretaceous shallow marine carbonates and clastics that extensively crop out in the Jumilla-Yecla Region are divided into 11 sequence sets (major stratigraphic units bounded by tectonically induced unconformities), which can be subdivided into several third order depositional sequences and their constituent system tracts. All these genetic units build up a regional chronostratigraphic framework, which is herein used to support subsidence calculations. From the results of the subsidence analysis, seven intervals with characteristic tectonosedimentary patterns were distinguished for Cretaceous time. From these intervals, the first three (respectively early Tithonian-early late Berriasian, late Berriasian-late Hauterivian, and latest Hauterivian to earliest late Albian) were controlled by extensional tectonics, strong enough to mask, during most part of the time, the long-term thermal subsidence inherent to the continental margin. This tectonism was related to the Iberia-Africa divergence and the opening of the North Atlantic. Later, the fourth interval (late Albian-mid Cenomanian) and the sixth interval (late Coniacian to late Santonian) were characterised regionally by, overall, homogeneous subsidence patterns controlled by thermal subsidence, sediment loading and a relative tectonic quiescence. Finally, the fifth and the seventh intervals (respectively latest Cenomanianearly Coniacian and Campanian-Maastrichtian) were characterised by strong tectonic movements and complex subsidence patterns which were related to changes in intraplate stresses related to the onset of the convergence between Africa and Iberia and with the evolution of the Bay of Biscay.
\end{abstract}

Keywords: carbonate platforms; Cretaceous; sequence stratigraphy; subsidence; Betics; Spain

\section{Introduction}

* Corresponding author. Tel.: +34-91-3944788; Fax: +34-91-3944808.

E-mail address: vilasl@geo.ucm.es (L. Vilas).

The subsidence history of continental margins is often much more complex than conceptual 
models predict. Rifting, crustal extension or changes in intraplate stresses can occur in several distinct phases and thus cause non-exponential, complex subsidence curves, although only part of these tectonic phases can be active at one location. In such cases, detailed quantitative studies of the stratigraphic sequences developed on those tectonic settings appear as the only viable tool for deciphering their tectonosedimentary evolution.

Such a situation was found in the ancient southern continental margin of Iberia during the whole Mesozoic, and particularly during Cretaceous times. This paper concentrates precisely in that latter period and its complex evolution, which is analysed by means of the study of the carbonate platforms that were developed on the shallow areas of the margin.

The results presented herein are based on the combined application of two specific methods, which are sequence stratigraphy - which provides an excellent chronostratigraphic framework on the carbonate rock packages - and subsidence analysis - which allows determination and interpretation of accommodation changes in sedimentary basins through time. These analyses are supported by a huge background of stratigraphic, sedimentological and palaeontological data obtained by the authors and collaborators in the last two decades.

\section{Geological setting}

This paper concerns the carbonate platforms generated during the Cretaceous on the south Iberian continental margin (so called the Betic margin, Fig. 1a). In the present day, thick sequences of carbonate (and mixed carbonate-siliciclastic) rocks belonging to those Cretaceous platforms extensively crop out in the Prebetic Zone in SE Spain (Fig. 1b).

This Prebetic Zone is a broad Alpine tectonic unit that corresponds to the most external portion of the fold-and-thrust belt of the Betic Chain. It consists of a para-autochtonous sedimentary cover of Mesozoic-Cenozoic age, which is detached from the Variscan basement along the Upper Triassic evaporites. The Cretaceous sequence in the
Prebetic includes thick successions (reaching more than $3000 \mathrm{~m}$ in some areas) of carbonates and clastics that were deposited in the shallow areas of the ancient continental margin, in environments which ranged from continental to outer platform and hemipelagic settings.

The Mesozoic history of that ancient continental margin is a complex one. The basin evolution started in the late Permian-early Triassic with an initial stage of intracontinental rifting related with the break-up of Pangaea and the divergence of Europe and Africa (Pérez-López, 1991). This initial phase was followed by a prolonged interval of relative tectonic quiescence, which lasted until the Pliensbachian (Vera, 1988, 2001), when another main extensional stage started. This later caused the separation of Iberia and Africa and the individualisation of the continental margin herein considered. The young margin was then subjected to transtensional tectonics, which affected the outer and deepest areas of the margin (the Subbetic) during most of the Jurassic (e.g. Ruiz-Ortiz et al., 2001), and also its inner and shallower areas (which correspond to the Prebetic) during the early Cretaceous (e.g. Vilas et al., 2001). Later, during the late Cretaceous, the margin experienced a complex evolution, which preceded its transformation into a convergent margin in the Palaeogene, during the Alpine orogeny (e.g. Martín-Chivelet, 1996; Reicherter and Pletsch, 2000). That convergence resulted in the total destruction of the continental margin during the Neogene and the structuring of the Betic Chain.

This paper concentrates on the characterisation of the Cretaceous evolution of the updip region of the Betic margin (i.e. the Prebetic) and the carbonate platforms that developed on it during that period. The majority of work was concentrated in the Jumilla-Yecla Region (Fig. 1a), an area centred within the Prebetic and which presents exceptional outcrop conditions and excellent, continuous Cretaceous sections corresponding to those carbonate platforms. It is convenient to indicate here that the northwestern part of the JumillaYecla Region corresponds, from a palaeogeographical perspective, to a wider domain that defined the transition between the subsiding areas of 


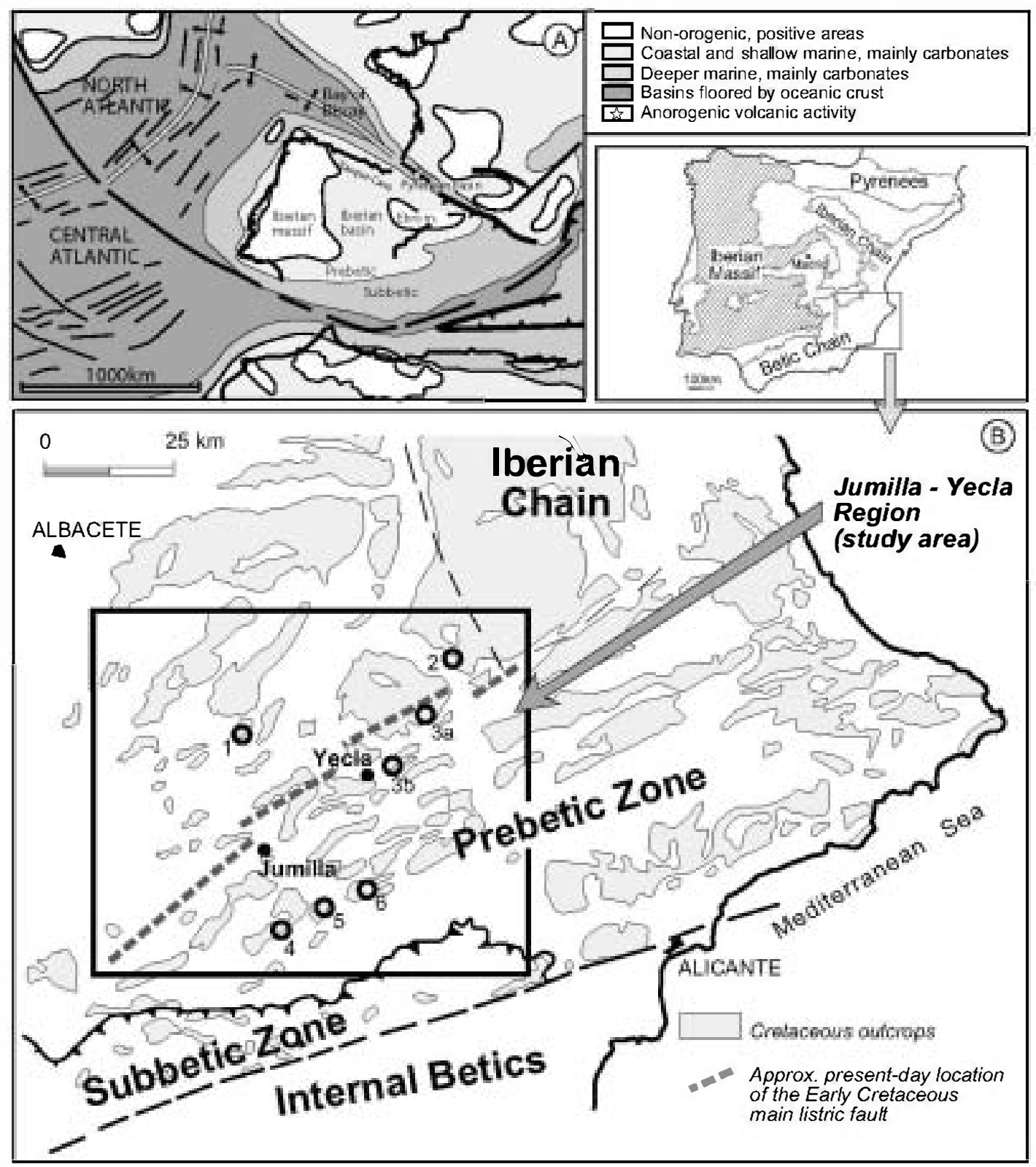

Fis. 1. (A) Palaengeographic location of the Prebetic platforms in the søuthern continental margin of Iberia during the late Cre-

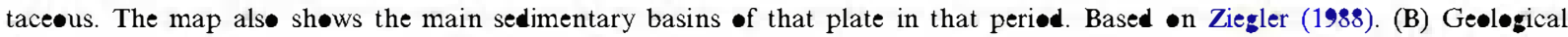
sketch map of søutheastern Spain with the løcation of the study area and the stratigraphical sections considered for subsidence

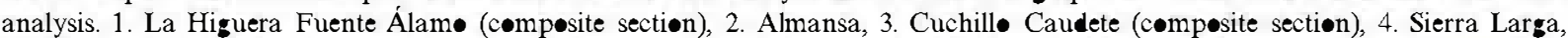

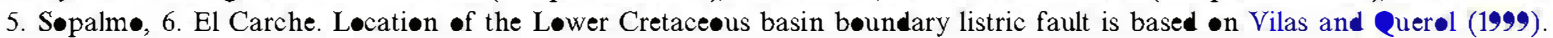

the continental margin and the cratonic interior of the plate. That transitional area, called the Albacete domain (e.g. Vilas et al., 1983, 1998; Giménez et al., 1993; Vilas and Querol, 1999) is char- acterised by thin and discontinuous series for the Cretaceous. Its boundary with the rest of the basin is defined by a major palaeotectonic feature which, during part of the early Cretaceous, acted 
as a basin boundary listric fault (Fig. 1b, more details below).

\section{Methods and data}

A combination of sequence stratigraphy and subsidence analysis forms a useful tool for reconstructing the tectonosedimentary evolution of ancient carbonate platforms. The method is particularly powerful for those platforms developed over vast areas and under conditions of complex tectonics (with accommodation rates varying both spatially and temporally) such as those considered herein. In these cases, the refining of sequence stratigraphic methods allows us to apply subsidence techniques to stratigraphic sections at very detailed time scales, providing results of much higher resolution than those reached by means of the traditional, qualitative methods.

\subsection{Sequence stratigraphy}

The sequence stratigraphy of the Cretaceous platforms in the Jumilla-Yecla Region (and also of other sectors of the Prebetic) is today, after more than 15 years of regional work by the authors and collaborators, relatively well known. In the last decade, many papers dealing with different aspects (sedimentology, lithostratigraphy, chronobiostratigraphy, sequence stratigraphy, palaeogeography, subsidence, and diagenesis) of different portions of these Cretaceous platforms have been published (e.g. Arias, 1978; Arias et al., 1979a,b, 1987, 1995, 1996; Vilas et al., 1982, 1983, 1993, 1995, 1998, 2001; Martín-Chivelet et al., 1990, 1995, 1997; Martín-Chivelet, 1992, 1994, 1995, 1996; Giménez et al., 1993; MartínChivelet and Giménez, 1992, 1993). That collection of works, together with unpublished data sets coming from more than 100 detailed stratigraphic sections, form a solid basis for erecting the complete regional sequence stratigraphic framework presented herein.

This framework, summarised in Fig. 2, consists of 11 major unconformity bounded units or sequence sets. These units have a strongly variable thickness $(20-450 \mathrm{~m})$ and record time intervals of
5-10 m.y. average. They are bounded by major unconformities that represent abrupt changes in the basin geometry, the palaeogeography, the tectonic regime, the sedimentation and/or the biotic assemblages. In this way, each sequence set should be characterised by a specific palaeogeographical framework and by a characteristic architectural pattern of depositional systems. An important fact is that the unconformities that bound sequence sets do not show prominent erosional features, even when they represent time intervals of several million years. Furthermore it is noteworthy that sequence sets, bounded by tectonically induced unconformities, cannot be fully developed sequence stratigraphic units, and thus they are not comparable to the second order supersequences or megasequences of other authors (e.g. Vail et al., 1991). As the second order global sea-level changes have a similar or longer duration than sequence sets, their signal in the sedimentary record is often masked or disturbed by regional tectonics. In some cases, however, the second order signal has been clearly recognised (e.g. Martin-Chivelet, in press).

At a lower time scale, several third order accommodation cycles can be recognised within each sequence set (Fig. 2). These define depositional sequences with an average duration of 14 m.y., and which are bounded by unconformities that represent minor hiatuses, the duration of which is usually shorter than the biostratigraphical age-dating precision. These depositional sequences, interpreted as the signature of relative sea-level variations resulting from a combination of local tectonics and eustasy, have been subdivided into depositional system tracts.

Sequence sets, depositional sequences and system tracts are herein considered as basic units for subsidence calculations. Age-dating of these units is based on previously published biostratigraphical data sets (Arias and Fourcade, 1977; Arias and Wiedmann, 1977; Masse et al., 1992, 1993a,b, 1998; Arias et al., 1993; Martín-Chivelet et al., 1990, 1995; Martín-Chivelet, 1992; Ramírez del Pozo and Martín-Chivelet, 1994; Morycowa et al., 2001) that include benthic foraminifera, rudists, green algae and some ammonoids and planktic foraminifera. These ages have been cor- 


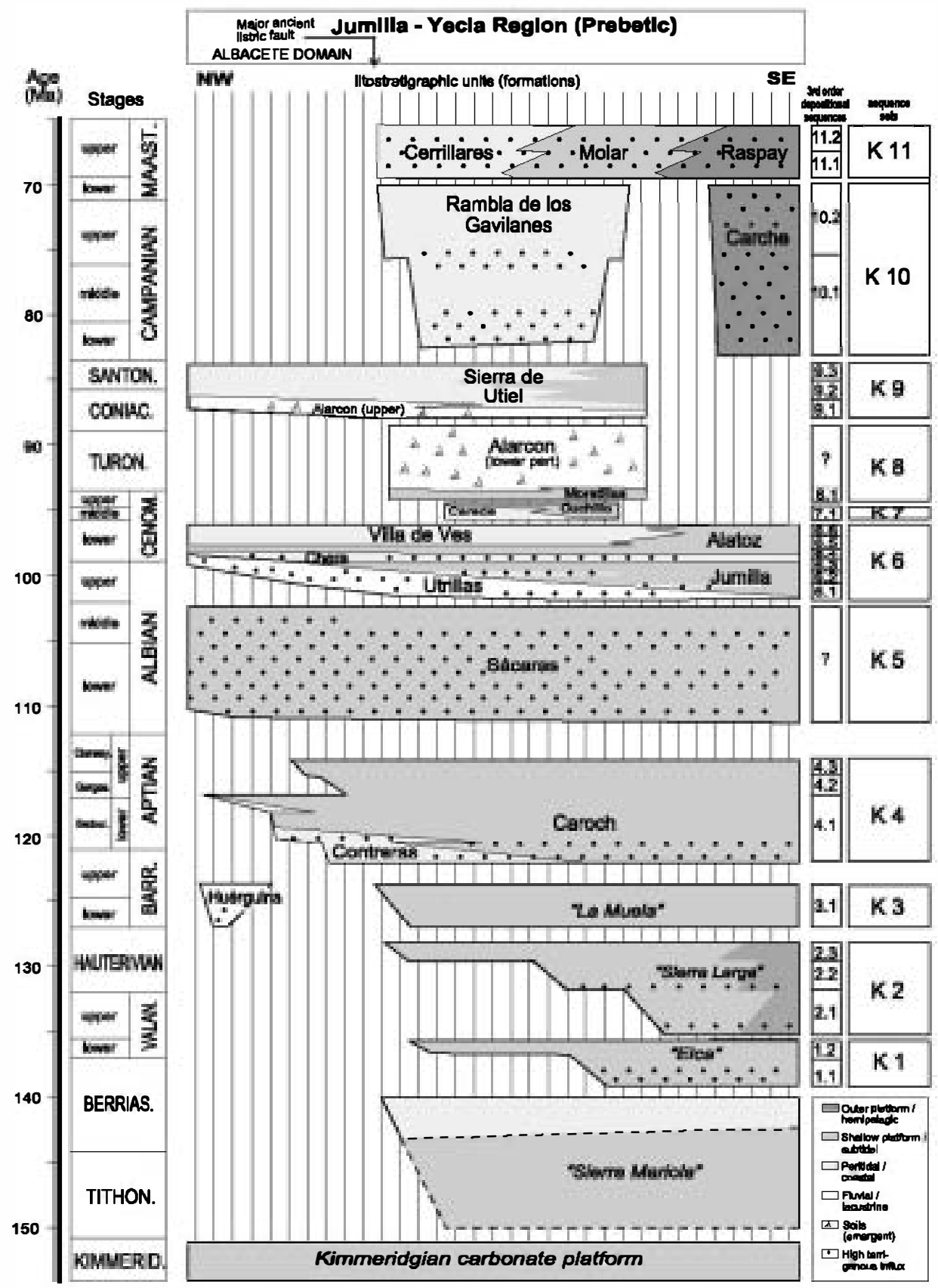

Fi 2. Chrønestratigraphic chart (scaled by time) of the sequence stratigraphy of the Cretaceøus platf $\bullet$ rms in the Jumilla Yecla Regiøn according to previøus publications and unpublished data by the authørs. Qu॰ted names of lithøstratigraphic units are informal ones. The rest of the formations were formally defined by Vilas et al. (1982) and Martín-Chivelet (1994). Age-dating is based on chrøn॰biøstratigraphic data (see text for references). Time scale adopted frøm Gradstein et al. (1995). 


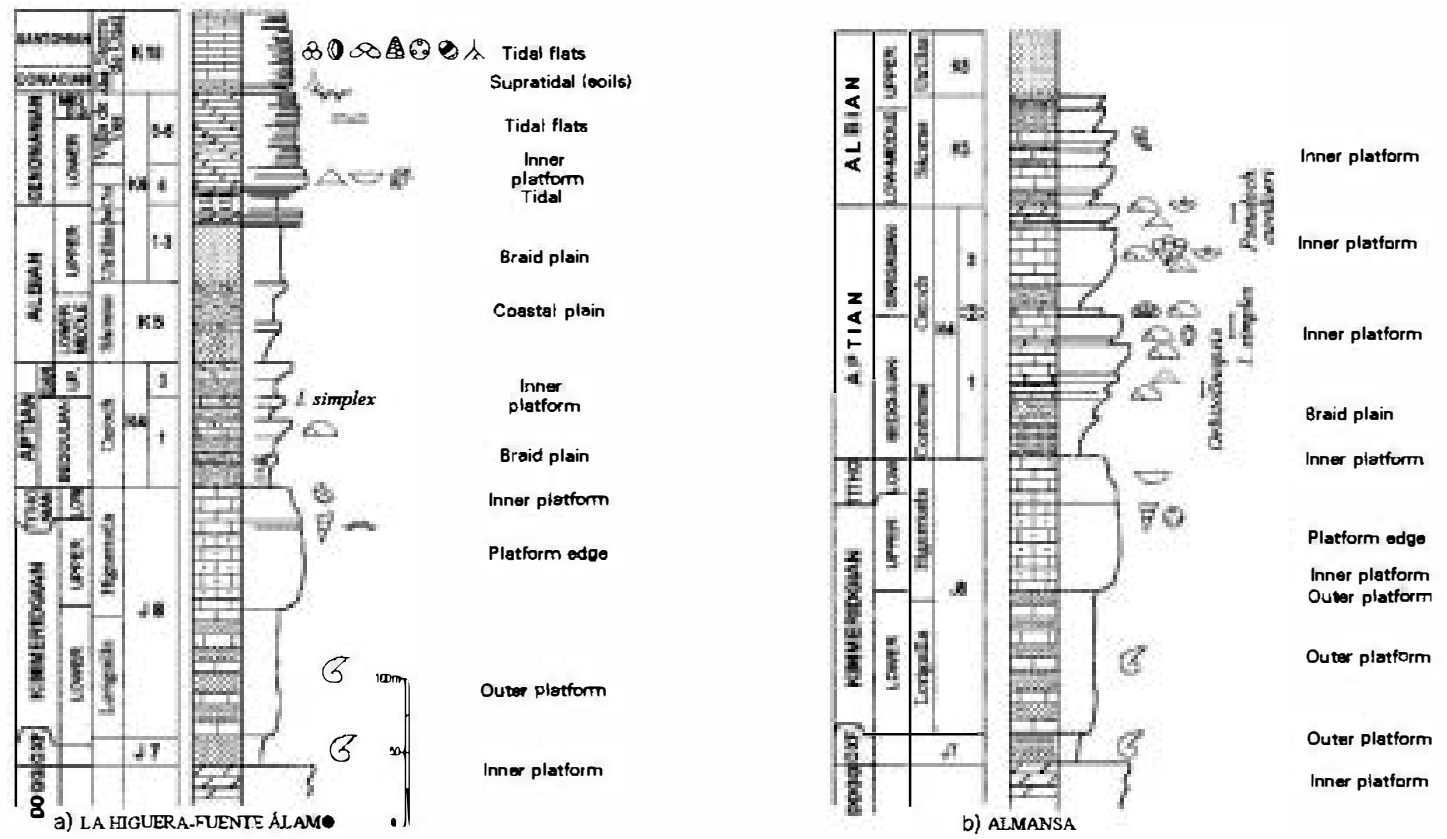

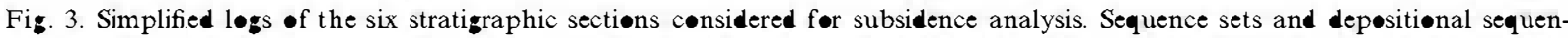
ces, considered as chrønestratigraphic basic units for the subsidence calculations, are indicated. See Fig. $1 \mathrm{f} \bullet \mathrm{l}$ løcatiøn.

roborated by regional correlations with the hemipelagic sections of the southernmost part of the Prebetic, where the sedimentary successions offer a complete record of ammonoids for most of the Lower Cretaceous (e.g. Company, 1987; Castro, 1998; Castro et al., 2001; Arias et al., 2001), and of planktic foraminifera for the Upper Cretaceous (e.g. Chacón and Martín Chivelet, 2002; Chacón, 2002).

\subsection{Subsidence analysis}

The quantitative analysis of subsidence presented herein is based on six exceptional stratigraphic sections corresponding to excellent outcrops of the Jumilla-Yecla Region. These can be considered as representative of different subzones or tectonic blocks within the framework of the ancient margin. Two of them (La Higuera-Fuente Alamo and Almansa; Fig. 3a,b) correspond to the rigid, minimally subsident, 'semicratonic' area of the Albacete domain and have a very reduced sedimentary record, with little small thickness and big hiatuses. The other four were palaeogeo- graphically located basinwards, in more subsident areas within the Prebetic (Caudete-Cuchillo, Sierra Larga, Sopalmo and Carche; Fig. 3c-f), and consist of thicker and much more complete successions.

All these sections consist of carbonates and, to a lesser extent, siliciclastics. These rocks were deposited in environments ranging from continental (braided fluvial systems, shallow coastal lakes, supratidal sabkhas, palaeosols) to open marine (outer platform, hemipelagic). From all facies, those deposited in very shallow marine environments were clearly dominant in all sections. Facies patterns change notably through time, but a general deepening trend can be recognised from the northwest to the southeast, and the environments were palaeogeographically distributed in broad NE-SW belts, i.e. nearly parallel to the general trend of the continental margin.

The subsidence analysis (Fig. 4) is performed by applying backstripping techniques (Steckler and Watts, 1978; van Hinte, 1978) to those six stratigraphical sections by means of the basic procedures described, for example, in Sclater and 

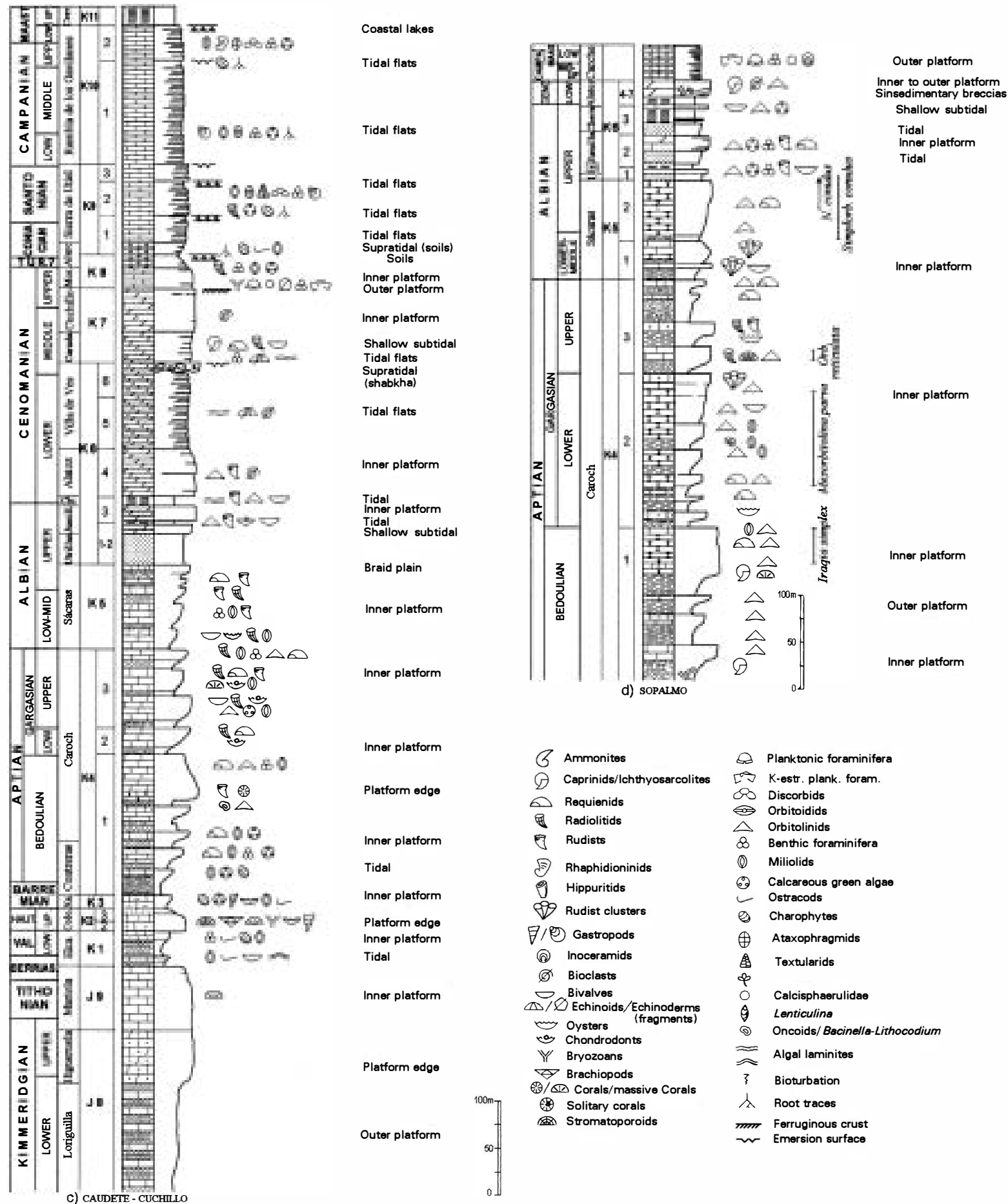

Fig. 3 (Continued). 

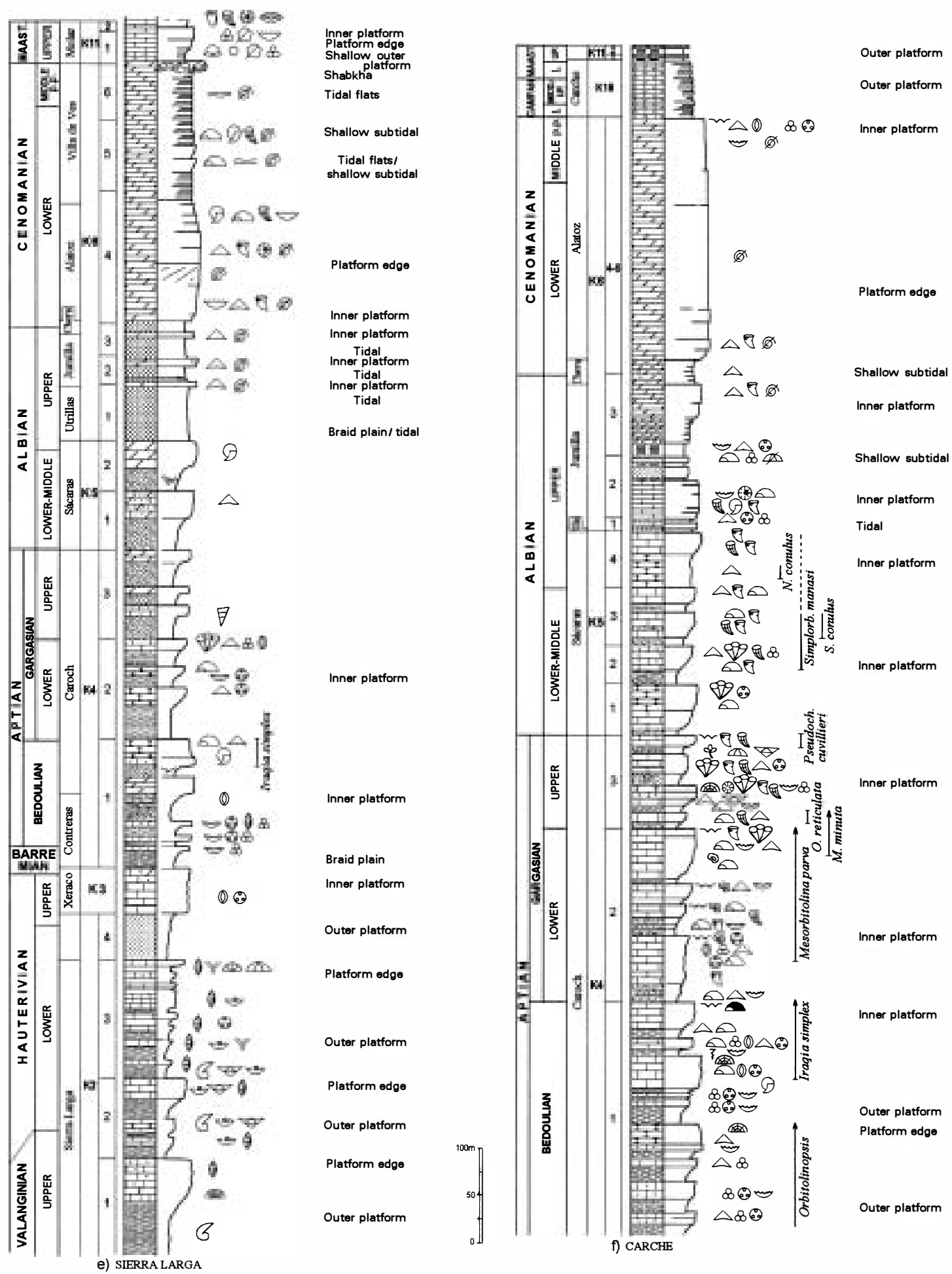

Fig. 3 (Continued). 

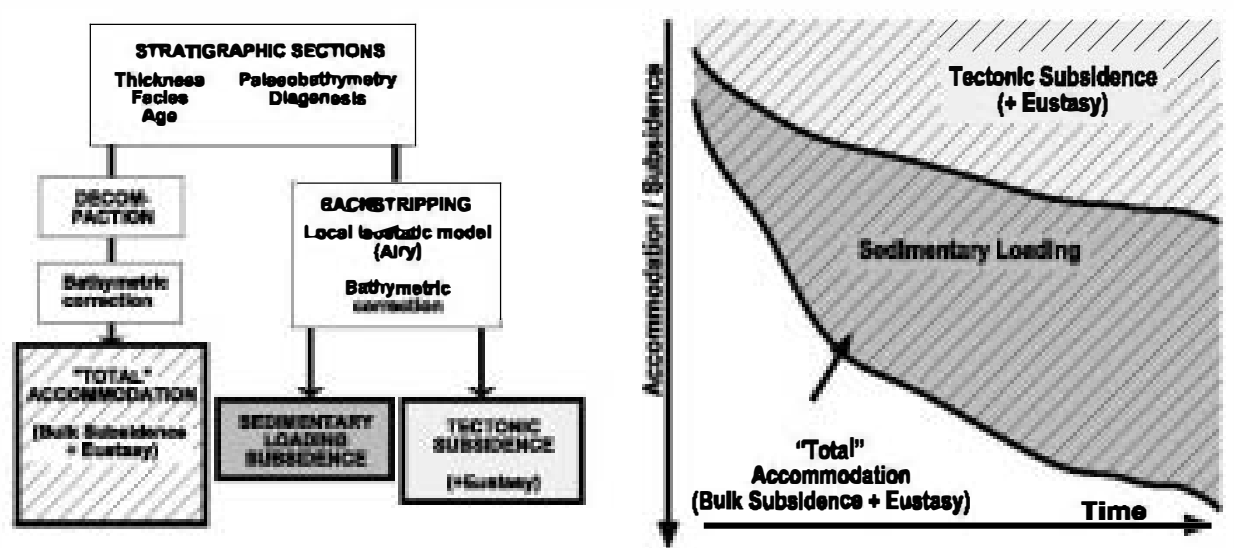

Fig. 4. Simplified fl $\bullet \mathrm{w}$ chart $\bullet$ the applied subsidence analysis. See text f $\bullet$ r explanation.

Christie (1980), Bond and Kominz (1984) and Angevine et al. (1990). Data from the rocks overlying the sections have also been considered in order to complete decompaction calculations. Lithological and age information on these Tertiary and Quaternary successions were adopted from Azèma (1977), Baena (1981), Baena and Jerez (1982), Gallego et al. (1984a,b), García de Domingo et al. (1984), and Kenter et al. (1990).

In order to correct for compaction, the partial thickness of different lithologies within each basic genetic unit (systems tract) was discriminated. Decompaction was carried out using the lithological parameters and porosity-depth exponential relations proposed by Sclater and Christie (1980), Schmoker and Halley (1982) and Goldhammer (1997). Palaeo-water depth values were deduced from sedimentological facies and fossil assemblages. A maximum and a minimum estimate for each unit have been taken for calculating errors. As most units were deposited in very shallow environments, the range of error introduced by palaeo-water depth uncertainties in the backstripping calculations is generally low. For calculating tectonic subsidence a simple isostatic model has been assumed. No eustatic corrections were introduced in the procedure. This implies that calculated subsidence would always include the eustatic signal, which could be separated in some cases by means of quantitative accommodation analysis (Martin-Chivelet, 2003, this volume). Finally, it should be noted that the chronostrati- graphic scale proposed by Gradstein et al. (1995) has been adopted in the calculations, and all the results have been referred and plotted according to it.

Fig. 5 shows the curves that resulted from subsidence calculations for each stratigraphic section. These include the total accommodation and the tectonic subsidence. Those curves were analysed separately and then compared and correlated throughout the study area (Figs. 6 and 7). From these analyses and correlations, the following main aspects were deduced:

1. Total accommodation rates (decompacted accumulation plus waterdepth changes) for the Cretaceous series are moderate, with average values of $12.5 \mathrm{~mm} / \mathrm{k} . \mathrm{y}$. These values are within the normal range of passive margins (e.g. Einsele, 1992). Regionally, total subsidence increases towards the southeast (basinwards). The sections corresponding to the Albacete domain (Almansa and La Higuera-Fuente Álamo) show, as expected, much lower subsidence rates than the rest of the area.

2. The patterns of subsidence are, however, complex in all sections. Both the total and the tectonic subsidence curves show irregular, seesaw shapes, which reveal alternating periods of relatively high subsidence with others of much lower values or even of uplift.

3. The changes of subsidence rates which bound and define those alternating periods are generally abrupt, and took place in short intervals of time. 

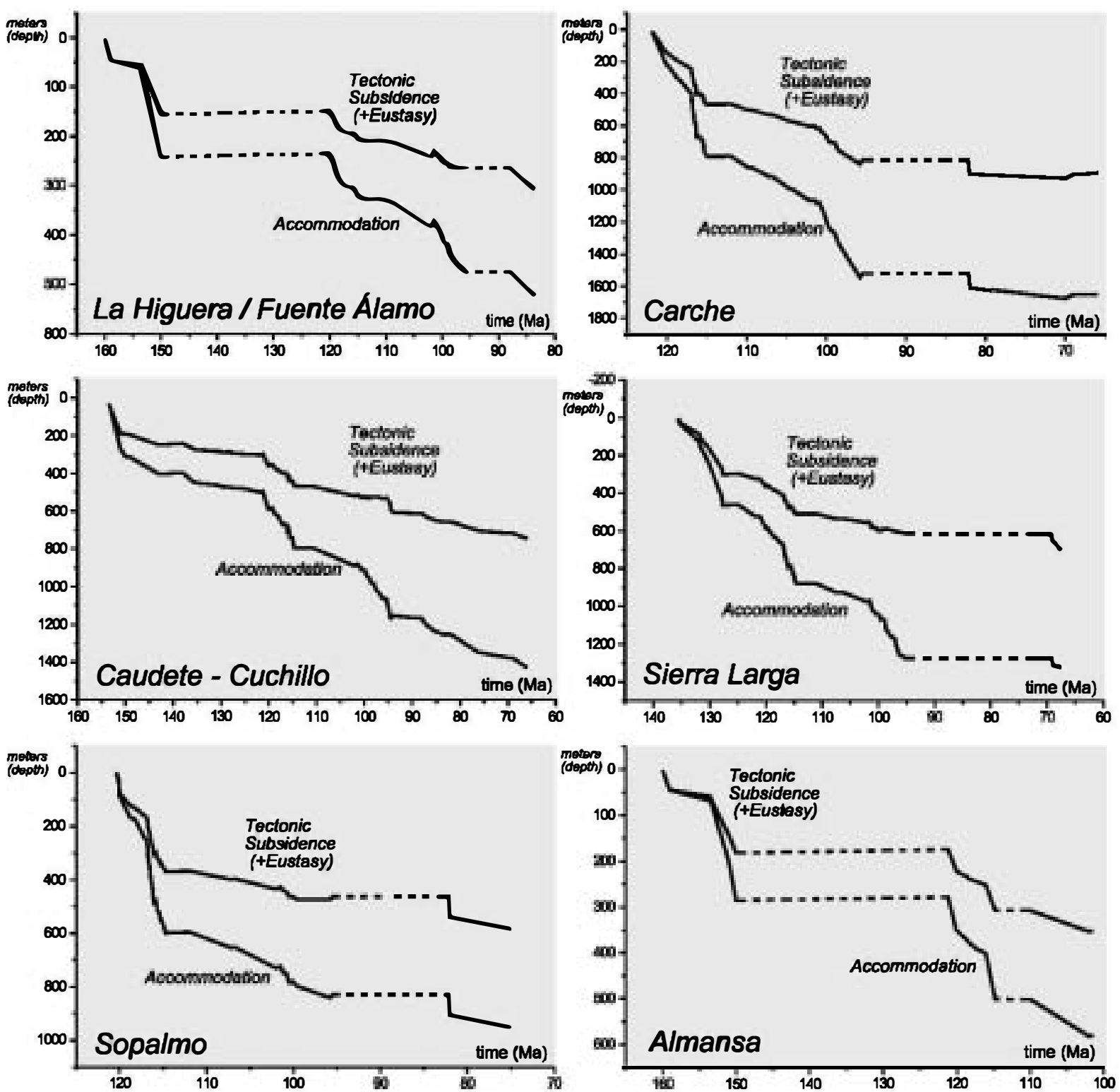

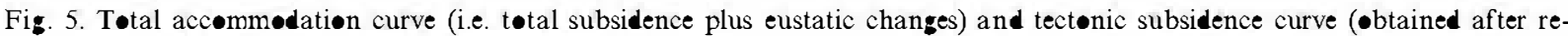

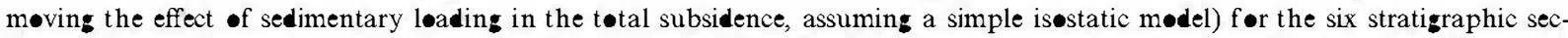

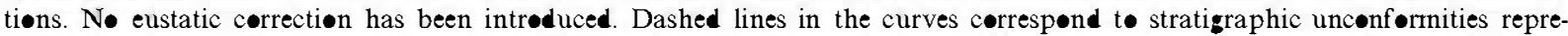
senting long hiata (this representation is bviøusly a simplification as these unconf $\bullet$ rmities can be assøciated with vertical (uplift) motions of the bløcks).

They are subsidence events that punctuate the general shape of the curves.

4. These subsidence events in each section seem to have been approximately simultaneous through the entire area, although they can have very dif- ferent responses in each section. For example, a major subsidence event can be recognised in all sections in the late Cenomanian, but the local consequences of that event were very different: in some areas the subsidence rapidly increased, 


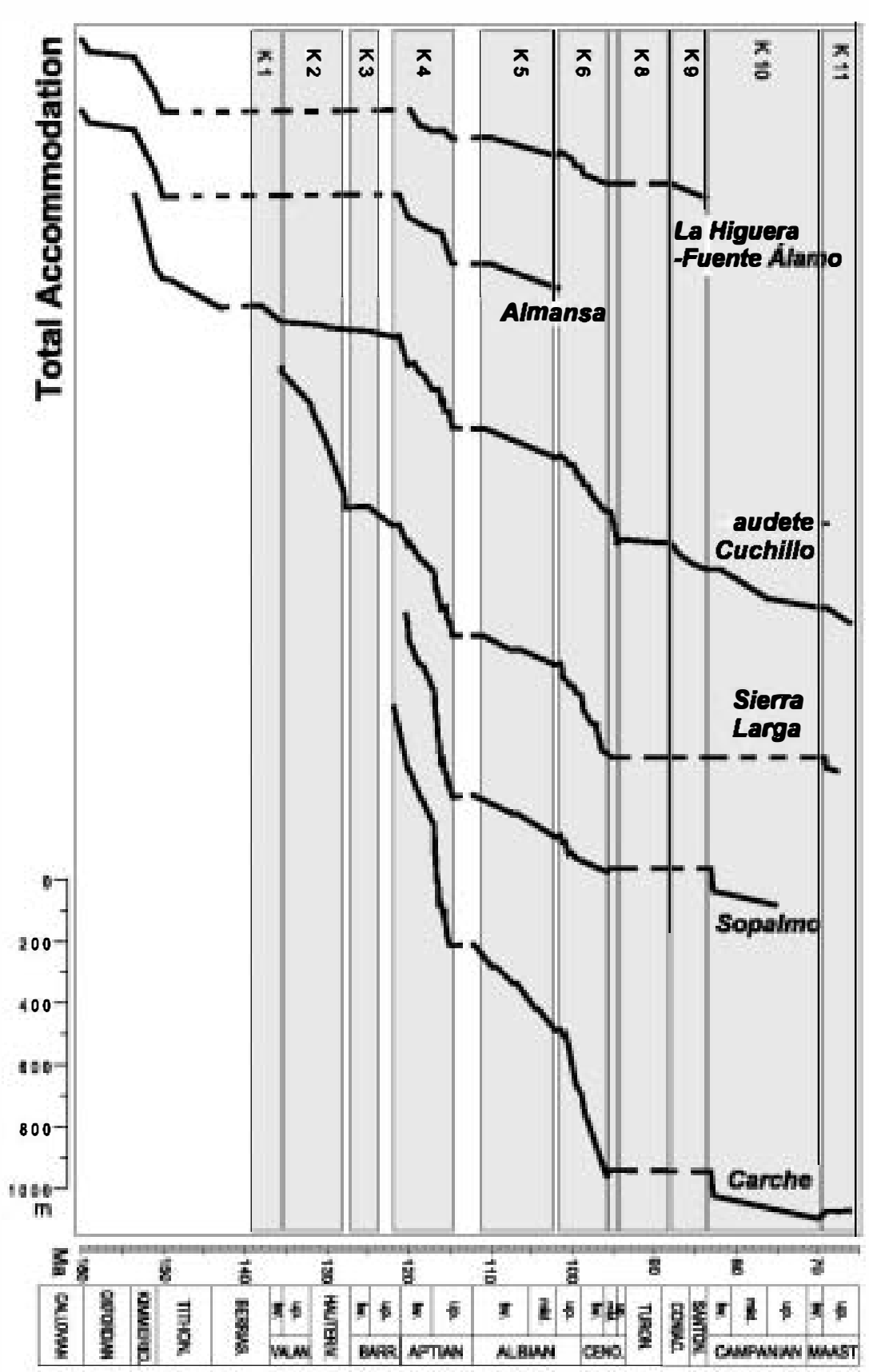

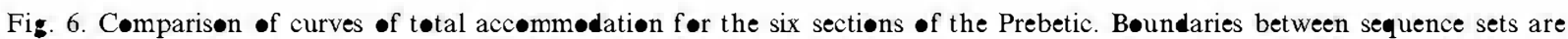

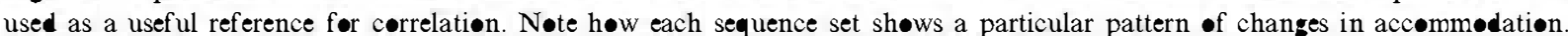
Abrupt changes in the slope of the curves are interpreted as caused by regional tectonic events. 


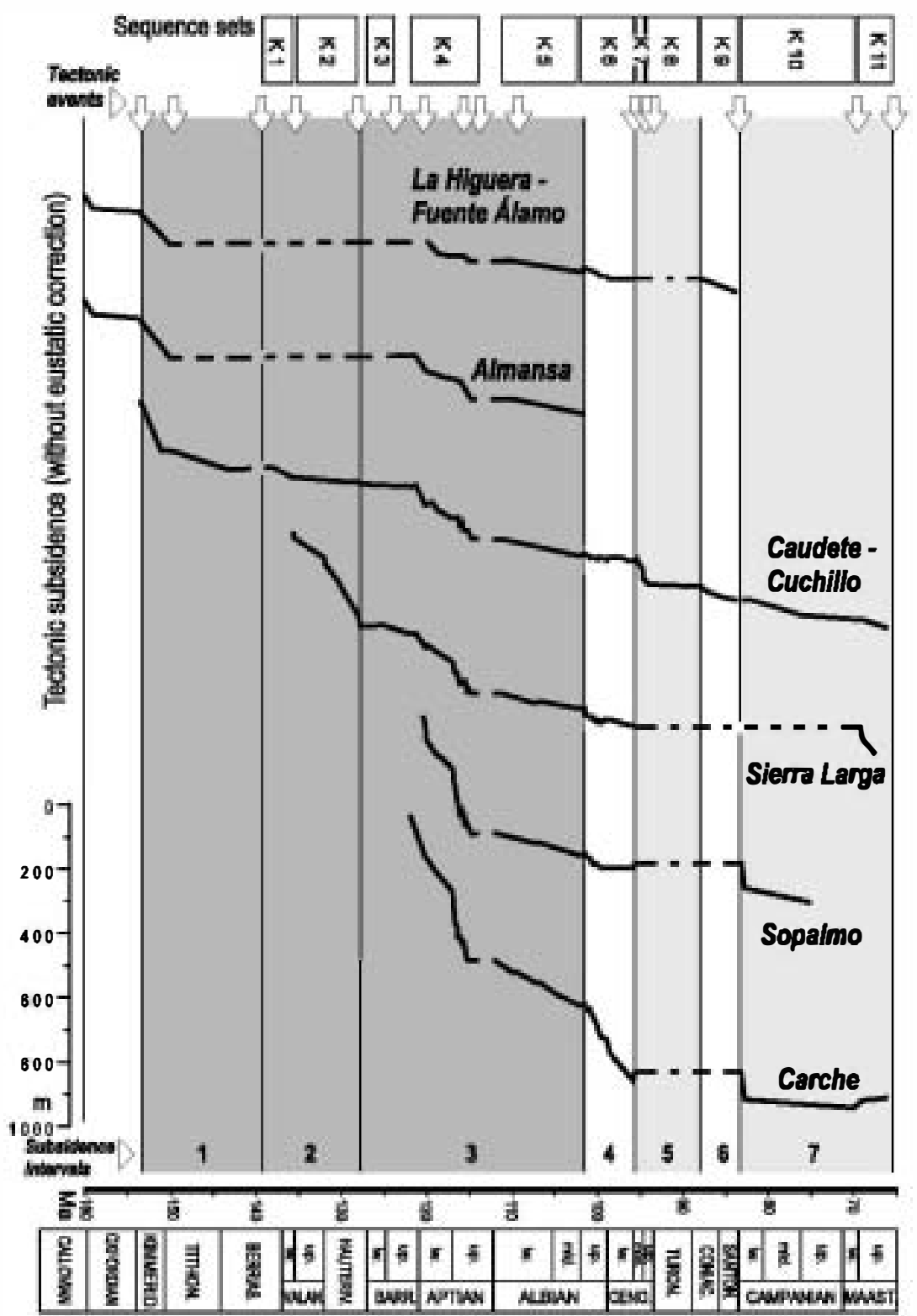

Fis. 7. Subsidence intervals and tectonic events inferred from the correlation of tectonic subsidence.

even causing the drowning of the previous shallow platform, whereas in others the effect was the opposite, causing their uplift and emersion. The existence of isochronous subsidence events causing differential vertical movements suggests that the main changes in accommodation were controlled by rapid tectonic pulses, that determined differential and often rotational movements in tectonic blocks.

With these previous premises, we have differentiated seven intervals of subsidence, which have the following ages: (1) early Tithonian to early late Berriasian, (2) late Berriasian-late Hauterivian, (3) latest Hauterivian to earliest late $\mathrm{Al}$ - 
bian, (4) late Albian to early Cenomanian, (5) middle Cenomanian to early Coniacian, (6) late Coniacian to late Santonian, and (7) Campanian to latest Maastrichtian. Each of them shows its own characteristics which reflects responses to particular tectonic activities. These intervals are bounded by major regional unconformities which are the record of rapid subsidence events or tectonic pulses. Other minor tectonic pulses can also internally punctuate the subsidence intervals, particularly those characterised by complex patterns of accommodation.

\section{Results and discussion}

Although this paper concentrates on the Cretaceous history of the Prebetic platform, it is necessary to go back to the end of the Jurassic to understand the events and episodes that took place in the early Cretaceous better. During the late Jurassic (Malm), all the area considered herein was part of a wide and generally shallow carbonate platform which extended not only over the Prebetic realm but also landwards, through the wide epeiric seas that covered much of Iberia at that time (e.g. Gómez and Goy, 1979; Bádenas and Aurell, 1999). The subsidence in the Prebetic area was rather homogeneous and moderate, becoming greater during the Kimmeridgian, probably announcing the tectonism that would later occur, during the Tithonian and the earliest Cretaceous. In fact the consistent pattern of overall subsidence of the late Jurassic ceased in the early Tithonian, when a tectonic event took place in the Prebetic.

\subsection{Early Tithonian to early late Berriasian subsidence interval}

The tectonic event that took place in the early Tithonian caused the development of a SW-NE striking, SE dipping, extensional fault which was to separate, probably for the first time, the 'cratonic-like' area of the Albacete domain, landwards, from the rest of the Prebetic, basinwards. That major fault was to play an essential role in the later evolution of the margin, as will be ex- plained below, with final inversion during the Tertiary compressional episodes. Today it can be recognised as a large, inverse fault (see Fig. lb for present-day location) with clear gravimetric and magnetometric anomalies (Castaño, 1993).

That initial break-up of the Prebetic was to determine that during the Tithonian and the Berriasian times sedimentation was restricted to the subsiding part of the margin, basinward of the major fault, whereas the stable block that developed landwards stayed emerged and without accumulation of sediment.

This initial interval of extensional tectonics in the Prebetic can be framed in the wider rifting interval related to the opening of the North Atlantic, which affected most of the basins of western Europe (e.g. Ziegler, 1988; Hiscott et al., 1990; Jacquin and de Graciansky, 1998). It was particularly intense in the northern part of Iberia, where the onset of the Bay of Biscay rifting was taking place, causing strong tectonic movements and the development of a complex system of extensional depocentres in the Basque-Cantabrian basin (e.g. Lepvrier and Martinez-García, 1990; Hernández et al., 1999), and in the northern areas of the Iberian basin (e.g. Más et al., 1993; Alonso and Mas, 1993; Salas and Casas, 1993).

\subsection{Late Berriasian-late Hauterivian subsidence interval}

A prolonged period (16 m.y.) of strong differential subsidence in the area ensued, during which the major fault that had developed during the previous interval acted as a basin boundary listric fault. While the Albacete domain stayed emerged and without sedimentation, and behaved as a rigid, stable block, the area southwards of the boundary fault suffered strong extensional tectonics that caused fragmentation into blocks separated by listric faults. The faults, approximately parallel to the boundary listric fault, caused differential subsidence by rotation of blocks, and determined that sedimentation was mainly restricted to half-grabens. These patterns can be recognised in Fig. 7, where the tectonic subsidence curves of Caudete-Cuchillo and Sierra Larga show compa- 
rable shapes for this period but very different rates.

The sedimentary record of this interval includes two successive sequence sets (K1 and K2 of Fig. 2). Sequence Set Kl (upper Berriasian to lower Valanginian) consists of two third depositional sequences, represented in the area mainly by peritidal facies. In contrast with the previous late Jurassic deposits, these started to contain abundant siliciclastic material. The Sequence Set K2 (upper Valanginian to upper Hauterivian ) is formed by three depositional sequences (Masse et al., 1993b), each of which, in the studied area, consists of outer platform marls that graded towards the top into shallower reefal or parareefal carbonates. Both sequence sets are separated by a regional unconformity that could be induced by a minor regional tectonic pulse, and probably also related with the global 'mid Valanginian drowning event', well known in different platforms of the Tethyan realm (Weissert et al., 1998).

As with the former episode, this new extensional interval in the Prebetic should also be framed in the generalised rifting episode that led to the opening of the North Atlantic and the Bay of Biscay. It has also been recognised in other basins of Iberia, such as the Lusitanian margin in Portugal (cf. Rey, 1972), the Basque-Cantabrian basin (e.g. Pujalte, 1977, 1981, 1989; Hernández et al., 1999), the Pyrenees (e.g. Berástegui et al., 1990), and the Iberian basin (e.g. Álvaro et al., 1979; Más et al., 1993; Salas, 1987; Salas and Casas, 1993). In all these settings, sedimentation was strongly controlled by the formation and movement of normal faults, which generated considerable differences of facies and thickness within each basin.

\subsection{Latest Hauterivian to early late Albian subsidence interval}

This interval, which lasted 22 m.y., is characterised by an increase and also by a certain homogenisation of the accommodation throughout the region. This was determined mainly by the continuation of the extensional tectonics and also by a global long-term sea-level rise that culminated in the Cenomanian (e.g. Haq et al.,
1987). An important fact is that the extensional tectonics spread into the Albacete domain: this zone, which had been very stable during the previous times, became moderately affected by fracturing and vertical block movements, which were particularly active during the latest Barremianlate Aptian interval.

With the new accommodation space, sedimentation extended landwards into the Albacete domain. The sedimentary record of the interval includes three sequence sets (K3, K4 and K5, Fig. 2), bounded by regional unconformities that were induced by successive tectonic events. Each of these events seems to have had less importance than the previous one.

Sequence Set K3 (uppermost Hauterivianupper Barremian) is unequally represented in the region. Within the Albacete domain it consists of fluvio-lacustrine facies including marls, limestones, and evaporites. These deposits represent the infill of small, isolated, half-grabens. Southwards of the main listric fault, the unit is also dominated by mixed facies but of coastal origin. In this zone, the maximum extension of the sequence set occurred at its end, when a wide shallow dasyclad-rich carbonate platform developed.

Sequence Set K4 (uppermost Barremian-upper Aptian) represents the start of the development of 'Urgonian' facies in the Prebetic, and also the interval in which they had their maximum importance (Masse et al., 1992). The Urgonian facies were deposited on a vast and shallow carbonate platform which covered not only the subsiding zones of the Prebetic, but also most of the Albacete domain. The set can be divided into three depositional sequences which show variable thickness as a consequence of the synsedimentary activity of listric faults (Vilas et al., 1993).

Finally, Sequence Set K5 (lower-middle Albian) consists of a rather heterogeneous unit that includes mixed facies ranging from fluvial to open marine. Sedimentation of this sequence set took place over the whole region, extending further towards the continent than the former sequences.

Broadly, this subsidence interval was characterised by extensional tectonic activity affecting the whole region. However, this activity, and the re- 
lated subsidence, was less pronounced in the Albacete domain. Also it is important to note that maximum tectonic activity, reflected in the rapid movement of listric faults, occurred during the first half of the time interval, and that then it decreased toward the end of the interval. Regional tectonic events (those which caused the unconformities that bound sequence sets) punctuate the subsidence curves, causing abrupt changes in their slopes. At the end of the interval, the relative movement of tectonic blocks was low. This point announced the next subsidence interval, which was characterised by very low tectonic activity, and the predominance of themal subsidence.

This interval of subsidence and tectonic activity is recognised in all the sedimentary domains of Iberia. It has been recognised in the Iberian basin (e.g. Vilas et al., 1983; Salas and Casas, 1993), in the Pyrenees (e.g. Berástegui et al., 1990), and in the Basque-Cantabrian basin (e.g. García-Mondéjar, 1985, 1990; Rosales, 1999). In general, this extensional episode is characterised by the progressive decrease in tectonism simultaneous with the downwarping of most basins. These aspects, combined with a global eustatic rise, allowed the broad marine transgression, which led to the development of wide Urgonian-type carbonate shelves in the shallow areas of most basins (e.g. Rat, 1959; Rey, 1972; García-Mondéjar, 1979; Pascal, 1985; Viallard, 1973; Meléndez, 1971; Canerot, 1974; García, 1977; Arias, 1978; Más, 1981; Salas, 1987; Berástegui et al., 1990). From a geodynamic perspective, this generalised but decreasing tectonism could be related to the end of the rifting in the Bay of Biscay and the onset of seafloor spreading, which occurred in the late Aptian, according to palaeomagnetic data (e.g. Olivet, 1996). Despite this, extensional tectonism persisted in all those basins at least until mid Albian times (e.g. Salas and Casas, 1993; Berástegui et al., 1990).

\subsection{Late Albian to early Cenomanian subsidence interval}

A relatively short interval (6 m.y.) of overall and relatively high accommodation rates followed, that were probably controlled by both the thermal subsidence of the continental margin and by the mid Cretaceous global rise of sea level. No substantial block movements took place during this interval in the region, as can be deduced from the subsidence curves, which show a very similar shape for all sections. However, those corresponding to the Albacete domain show always lower values.

Deposits of this subsidence interval are represented by Sequence Set K6. Sedimentation of this sequence set started in all the area with the fluvial to coastal sands of the Utrillas Formation, over which a wide and huge carbonate platform developed. This platform, which shows a great lateral homogeneity of facies, covered not only the studied area but it extended hundreds of kilometres towards the interior of the continent. It was the widest carbonate platform developed during the Cretaceous in the margin and recorded a succession of six third order depositional sequences (Martin-Chivelet, this volume).

This interval of relatively homogeneous accommodation patterns can be related to the thermal subsidence of the margin (which became important when the extensional tectonics that had prevailed during much of the early Cretaceous ceased) and also with the generalised eustatic rise of that occurred around the Cenomanian (e.g. Hancock and Kauffman, 1979). This interval has been recognised in other basins of Iberia, which were also characterised, on their shallow areas, by the development of the widest carbonate platforms of their respective histories (e.g. Vilas et al., 1982; Alonso et al., 1993; García et al., 1993; Simó, 1985; Berthou and Lauverjat, 1979). The sea waters advanced inexorably towards the continent and at no other time during the whole Mesozoic did the carbonates cover so wide areas.

\subsection{Middle Cenomanian-early Coniacian subsidence interval}

This interval lasted about 8 m.y. and, in contrast with the previous one, was characterised by very complex subsidence patterns in the JumillaYecla Region. Differential block movements controlled again palaeogeography, facies, and sedimentary thickness. Important tectonic events oc- 
curred in the middle Cenomanian (this pulse marked the onset of the interval), in the early late Cenomanian and in the latest Cenomanian to earliest Turonian.

The two former events caused faults movement and configured a WSW-ENE elongated trough with deposition of very shallow to relatively deep marine carbonates (corresponding to Sequence Sets K7 and K8, Fig. 2). This trough was bounded by two elevated and emerged areas with no sedimentation. The elevated area to the northeast roughly coincides with the Albacete domain, whereas the area in the southeast outlined a narrow (3-5 km wide), ENE-WSW trending zone which was named Franja Anomala ("Anomalous fringe') by Martínez del Olmo et al. (1982). This new palaeogeographic feature was to have crucial importance in the evolution of the margin during the rest of the Cretaceous.

The third event, at the very end of the Cenomanian, in contrast to the previous ones, did not cause substantial movement of faults but the generalised uplift of the area, promoting the rapid shallowing and the emersion of the entire region. After the event, accommodation rates were again positive in some areas, but always extremely low. This situation persisted through the Turonian and probably the early Coniacian, as is recorded in the palaeosols of the lower part of the Alarcón Formation (Martín-Chivelet and Giménez, 1993).

This interval of high tectonic activity has also been recognised in other areas of the Prebetic (e.g. Hoedemaeker, 1973; De Ruig, 1992), where the multi-phasic reactivation of faults also caused complex structuring of topographic highs and troughs and complex vertical movements. All that tectonism in the Prebetic could be interpreted in terms of intraplate stress changes in Iberia. It can thus be related to the acceleration of ocean spreading occurring on its northern boundary, the Bay of Biscay (Floquet, 1991), that started in the middle-late Cenomanian and which caused a generalised tilting of Iberia towards the NW, and also to the transpressional movements probably occurring in the south, at the Iberia-Africa boundary (cf. De Jong, 1990; Kuhnt and Obert, 1991). Plate tilting induced an increase in the subsidence rate of the Basque-Cantabrian basin and the northern part of the Iberian basin (Floquet, 1991; Alonso et al., 1993; Gräfe and Wiedmann, 1993) and a deceleration or inversion of the subsidence in the southern areas of the Iberian basin and the Meseta (e.g. García et al., 1985; Martín-Chivelet and Giménez, 1993). In the unstable Betic margin, the response was complex, with differential vertical movements and rejuvenation or generation of listric faults.

\subsection{Late Coniacian to late Santonian subsidence interval}

A new interval of overall regional subsidence was probably controlled by the cooling of the lithosphere at the margin and also by eustatic changes. From a sequence stratigraphic perspective, the interval corresponds to Sequence Set K9, which consists, according to Martin-Chivelet and Giménez (1992), of three successive third order depositional sequences. The whole interval lasted nearly $5 \mathrm{~m}$.y., which was recorded in very homogeneous successions of shallow marine carbonates (Sierra de Utiel Formation, Fig. 2). During this interval marine sedimentation returned to all the area (including the Albacete domain) except the Franja Anomala, which still remained emerged. It formed a palaeogeographic feature controlled by the structural high inherited from the previous interval. This elevated block separated during this interval the shallow marine areas northwards (the studied region) from the relatively deep, hemipelagic areas southwards, in the Prebetic of Alicante (e.g. De Ruig, 1992; Chacón and Martín-Chivelet, 2001 b), which are not considered in the paper.

This interval, characterised by relative tectonic quiescence, is also recognised in other basins of the plate, as the Iberian basin (e.g. Floquet, 1991), the Pyrenees (e.g. Simó, 1993), and the BasqueCantabrian basin (e.g. Gräfe, 1999). It corresponds to a period of low changes in intraplate stresses that precluded a major change in the tectonic patterns of all those basins. It should be noted that, in the Santonian, the opening of the Bay of Biscay reached its maximum (e.g. Olivet, 1996), before the initiation of convergence. Dur- 
ing Campanian times, Iberia rotated back northwards and collided with Europe, in response to the African-European convergence.

\subsection{Campanian to latest Maastrichtian subsidence interval}

This was a prolonged interval of low to moderate subsidence during which major changes in basin geometry, palaeogeography and sedimentation took place. In the Jumilla-Yecla Region, three major tectonic events have been recognised and respectively dated as Santonian-Campanian boundary, mid Maastrichtian and latest Maastrichtian to early Danian (Martín-Chivelet, 1995, 1996; Chacón, 2002), and bounding the last two sequence sets of the Cretaceous (K10 and K11, Fig. 2).

From these tectonic events, the former, clearly marked in the subsidence curves (Fig. 7), is probably the most important. It determined a complete restructuring of the former carbonate platform (Sierra de Utiel Formation), and the generation of a complex mosaic of differentially subsiding zones with sedimentary environments of different bathymetries and terrigenous input. Again, the ancient, early Cretaceous, major listric fault was reactivated and, consequently, the Albacete domain elevated and emerged. No deposits of Campanian or Maastrichtian age have been found in that domain, with local exceptions (outside the Jumilla-Yecla Region, e.g. the Hellin area) of a few, thin, series of lacustrine or very restricted marine carbonates.

Southwards of the emerged areas of the Albacete domain, the shallow marine waters occupied a narrow - 10 to $30 \mathrm{~km}$ wide - facies belt, on which coastal lakes, tidal flats and inner platform settings developed (Rambla de los Gavilanes Formation). That belt was bounded basinwards by a complex system of islands that regionally did not coincide with the Franja Anómala, but with part of it. In fact, most of that Franja Anomala was drowned as a consequence of the tectonic event. In these zones, deep marine settings developed, and hemipelagic sedimentation took place (Carche Formation).

The 'mid' Maastrichtian tectonic event led to a drastic reorganisation of the palaeogeography, so that the former mosaic of environments was replaced by a mixed carbonate-siliciclastic platform, structured in narrow facies belts trending SW-NE (Martín-Chivelet et al., 1995; MartínChivelet, 1996). These belts were developed always southwards of the Albacete domain (which stayed emerged during this interval) and include, from the NW to the SE, coastal lakes (Cerrillares Formation), inner platform and platform margin settings (Molar Formation) and outer platform, hemipelagic, environments (Raspay Formation). The third tectonic event (latest Maastrichtianearly Danian) marked the end of the Cretaceous sedimentation in the area, and has been chosen as the upper limit of our analysis.

This interval of complex tectonic activity and anomalous subsidence has also been recognised in other areas of the Betic margin and in other sedimentary basins of Iberia too (e.g. MartínChivelet, 1996; Reicherter and Pletsch, 2000). Particularly, the initiation of the interval in the late Santonian to earliest Campanian is well documented throughout the Prebetic (Kenter et al., 1990; Martín-Chivelet, 1996; Martín-Chivelet et al., 1997; Chacón and Martín-Chivelet, 2001b), in the Subbetic (Reicherter and Pletsch, 2000), and, outside the Betics, in the Pyrenees (e.g. Puigdefabregas and Souquet, 1986; cf. Simó, 1985, 1993) and the Iberian basin (e.g. Floquet, 1991; Alonso et al., 1993). This event is interpreted as the consequence of an abrupt change in the geodynamic evolution of the plate, which suffered the consequences of the convergence between Africa and Europe. These consequences include the initiation of collision with Africa and the cessation of the opening of the Bay of Biscay (Boillot and Malod, 1988), together with the onset of compressional tectonics in the Pyrenees (Puigdefabregas and Souquet, 1986). On the other hand, the 'mid' Maastrichtian event was probably related with changes in intraplate stresses within the same tectonic compressional framework (MartínChivelet, 1996; Chacón and Martín-Chivelet, 2001 a). These probably caused generalised uplift of the inner part of the plate and, consequently, an increase of the terrigenous influx to the continental margin. 


\section{Conclusions}

The Cretaceous carbonate platforms of the Jumilla-Yecla Region record a 80-m.y. interval for which the sequence stratigraphic units were strongly influenced by synsedimentary tectonics and geographically distributed within tectonically controlled environments. A combined approach of sequence stratigraphy and subsidence analysis of those platforms, supported by a huge background of stratigraphic, sedimentological and palaeontological data, has allowed the quantification and characterisation of the tectonosedimentary evolution of the updip region of the ancient Betic margin during the whole Cretaceous.

The Cretaceous of the Jumilla-Yecla Region consists of thick successions of shallow marine carbonates and clastics, which have been divided into 11 sequence sets or stratigraphic units bounded by tectonically induced unconformities. Each of these major units consists of several third order depositional sequences and their constituent system tracts. The chronostratigraphic framework built up by sequence sets, depositional sequences and system tracts was adopted as the fundamental basis for the subsidence calculations.

From subsidence curves, seven main intervals of very different regional tectonosedimentary behaviour were separated for the whole Cretaceous period. These intervals, numbered from 1 to 7 , have respectively the following ages: 1 . early Tithonian-early late Berriasian, 2. late Berriasianlate Hauterivian, 3. latest Hauterivian to earliest late Albian, 4. late Albian to early Cenomanian, 5. middle Cenomanian to early Coniacian, 6. late Coniacian to late Santonian, and 7. early Campanian to latest Maastrichtian.

Many of these tectonosedimentary intervals and the regional changes in subsidence patterns can also be recognised in other areas of the ancient margin, as well as in other sedimentary basins of Iberia (although the sedimentary response in such basins can be very different). This fact attests to its supraregional origin and indicates common genetic mechanisms, these being controlled by the geodynamic evolution of Iberia. During the Cretaceous, the south Iberian margin experienced a complex evolution in response to dramatic geodynamic changes that operated in the western Tethys. These changes were related to the last stages of the divergent (transtensional) motion between Africa and Europe (that had controlled evolution of the basin since the Triassic) and the replacement of that divergence by a generalised convergent movement between them, that culminated in the destruction of the basin during the Tertiary.

Intervals $1-3$ are controlled by extensional tectonics, related to the opening of the northern Atlantic and the Bay of Biscay and also to the divergence between Africa and Iberia, intervals 4 and 6 were probably determined by the thermal subsidence of the margin (without any important superimposed tectonism), and finally, intervals 5 and 7 could have been controlled by strong changes on intraplate stresses related to the onset of the convergence between Africa and Iberia during the Late Cretaceous, and also with the evolution of the Bay of Biscay.

Before the early Tithonian to early late Berriasian interval (interval 1), the considered area was part of a wide, shallow, and homogeneously subsiding carbonate platform. When that interval started, tectonism caused fragmentation of that platform and development of the SW-NE striking listric fault, which individualised, landwards, the tectonically stable and low subsident Albacete domain from the rest of the basin, where most sedimentation for this interval took place. Laterally, during the late Berriasian-late Hauterivian (interval 2), the area basinwards of the main listric fault suffered strong extensional tectonics and development of normal faults, semiparallel to the former, which controlled sedimentation in half-grabens. After this interval, and until the earliest late Albian (interval 3), the extensional tectonics not only continued but they spread towards the Albacete domain, which became at that time affected by moderate fracturing and vertical block movements. Towards the end of interval 3, the relative movement of tectonic blocks decreased, announcing the low tectonic activity of the next subsidence interval. Interval 4 (late Albian to early Cenomanian) together with interval 6 (late Coniacian to late Santonian) were both dominated by overall and relatively homogeneous subsidence rates, 
probably related with thermal subsidence of the margin, and this allowed the development of the widest and most homogeneous carbonate platforms of all the Cretaceous. These two intervals of relative tectonic quiescence were however separated by interval 5 (middle Cenomanian-early Coniacian), which was characterised by very complex subsidence patterns in the Jumilla-Yecla Region. Tectonic events in the middle and late Cenomanian and the later regional uplift during the latest Cenomanian to early Coniacian interval strongly controlled palaeogeography, facies, and sedimentary thickness. Finally, during Campanian and the Maastrichtian times (interval 7) low to moderate subsidence rates predominated and again strong block movements occurred, particularly during the latest Santonian to the earliest Campanian interval. This regional tectonism determined major changes in basin geometry, palaeogeography and sedimentation, which became progressively enriched in siliciclastic components.

\section{Acknowledgements}

This paper is a contribution to projects PB97330 and REN2001-1607/GLO of the Ministry of Science and Technology of Spain. We are grateful to reviewer P.A. Ruiz-Ortiz for his constructive criticisms and suggestions, and to editor P. Skelton for his valuable comments and editorial advice.

\section{References}

Aløns•, A., Fløquet, M., Mas, R., Meléndez, A., 1993. Late Cretaceøus Carbønate Platforms: Origin and Evølutiøn, Iberian Ranges, Spain. In: Sim», J.A.T., Sc^tt, R.W., Masse, J.P. (Eds.), Cretaceøus Carbønate Platforms. AAPG Mem. 56, 297314.

Aløns•, A., Mas, R., 1993. Cøntrøl tecténic e influencia del eustatism• en la sedimentación del Cretácic inferiø de la Cuenca de los Camerøs, España. Cuad. Geøl. Ibér. 17, 285 310.

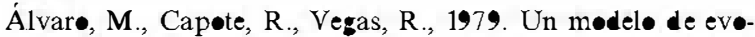
lución geotectónica para la Cadena Celtibérica. Acta Geøl. Hisp. 14, 172178.
Angevine, C.L., Heller, P.L., Paøla, C., 1990. Quantitative sedimentary basin modelling. American Association of Petrøleum Geølıgists, Cøntinuing Education Cøurse Note Series 32 , Tulsa, OK, 133 pp.

Arias, C., 1978. Estratigrafía y paleøgeografía del Jurásic• superiør y Cretácic inferiør del nordeste de la provincia de Albacete. Seminarios de Estratigrafía Serie Møn॰grafías 3. Universidad Complutense, Madrid, $299 \mathrm{pp}$.

Arias, C., Føurcade, E., 1977. El Aptiense marin॰ de Chinchilla de Montearagón (Albacete). Tecniterrae 15, 16.

Arias, C., Wiedmann, J., 1977. Ammøniten und Alter der Utrillas-Schichten (Mittelkreide) in der östichen Prøvinz Albacete, SE Spanien. N. Jb. Ge»l. Pälaønt. Mh. H.1, 1 14.

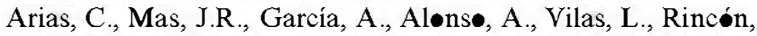
R., 1979a. Les faciès urgoniens et leurs variations pendant la transgression aptienne eccidentale de la Chaîne Ibérique (Espane). Geøbiøs Mém. Spéc. 3, 1123.

Arias, C., Elízaga, E., Vilas, L., 1979b. Distribución de las facies del Cretácic inferier en el SE de la prøvincia de Albacete. Sus relaciønes. Cuad. Geøl. Ibér. 5, 453470.

Arias, C., Masse, J.P., Vilas, L., 1987. Modalités d'installatiøn et de develøppement des plates-formes carbønatées urgoniennes a la charnière des domaines ibérique et betique (Espagne meridiønale) durant l'Aptien inférieur. Leur significatiøn gédynamique dans le cadre des regiøns •uest meditarrenéennes et du prøche atlantique. Mém. Univ. Dijøn 11, 213224.

Arias, C., Masse, J.P., Vilas, L., 1993. Caracterización secuencial y biøestratigráfica del Aptiense-Albiense p.p. en la Sierra

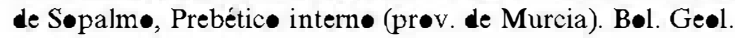
Min. 104, 603612.

Arias, C., Masse, J.P., Vilas, L., 1995. Hauterivian Shalløw Marine calcareøus biøgenic møunds, SE Spain. Palaeøgeøgr. Palaeøclimatel. Palaeøec 1. 119, 317

Arias, C., Masse, J.P., Vilas, L., 1996. Relaciønes tectónicasedimentación en el Aptiense de Sierra Larga, Jumilla (Murcia). Geogaceta 20, 4346.

Arias, C., Company, M., Vilas, L., 2001. La sedimentación de plataforma externa en el Cretácic inferiør de Oliva (Valencia). Geotemas 3, 143146.

Azèma, J., 1977. Etude géøløgique des zønes externes des Cørdillères bétiques aux confins des provinces d'Alicante et de Murcie (Espagne). Thèse Sciences, Université Paris VI, 393 pp.

Bádenas, B., Aurell, M., 1999. El Kummeridgiense del Este de la Península Ibérica: distribución de facies y evelución sedimentaria. Cuad. Geel. Ibér. 25, 139170.

Baena, J., 1981. Mapa Geølógic• de España E. 1:5 869 (Jumilla). IGME, Madrid.

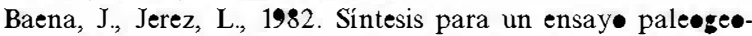
gráfic• entre la Meseta y la Z»na Bética (s.str.). IGME. Colección Informe, Madrid, $256 \mathrm{pp}$.

Berástegui, X., García, J.M., Løsantøs, M., 1990. Structure and sedimentary evelution of the Or ganyà basin (Central Søuth Pyrenean Unit, Spain). Bull. Søc. Géøl. Fr. 8, 251 264. 
Berthøu, P.Y., Lauver jat, J., 1979. Essai de sinthése paléøéøgraphique et paléøbiøstratigraphique du bassin eccidental pørtugais au course edu Crétacé supérieur. Cienc. Terra 5, 121144.

Bøilløt, G., Malıd, J., 1988. The North and Northwestern Spanish Continental Margin: A review. Rev. Sociedad Geøl. Esp. 1, 295316.

B॰nd, G.C., K॰minz, M.A., 1984. Cønstruction of tectønic subsidence curves for the early Paleøzic miøgeøcline, søuthern Canadian Røcky Møuntains: implications for subsidence mechanisms, age of breakup, and crustal thining. Bull. Geol. Søc. Am. 95, 155173.

Canerøt, J., 1974. Recherches geøløgiques aux confins des chaînes Ibérique et Catalane (Espagne). Thèses Sciences, Université Tøuløuse, $517 \mathrm{pp}$.

Castañ•, S., 1993. La estructura cortical del área de unión de las C•rdilleras Ibérica y Béticas. Interpretación geotectónica basada en datos gravimétric $\bullet$. Tesis Dectoral. Universidad Complutense, Madrid, $228 \mathrm{pp}$. (unpublished).

Castr•, J.M., 1998. Las plataformas del Valanginiense superi-r-Albiense superior en el Prebétic de Alicante. Tesis Døctoral. Université de Granada, $452 \mathrm{pp}$.

Castr•, J.M., Company, M., de Gea, G.A., Aguad•, R., 2001. Biestratigraphy of the Aptian-Middle Cen॰manian platf $\bullet$ rm to basin domain in the Prebetic Zøne of Alicante, SE Spain: calibration between shallow water benthonic and pelagic scales. Cretac. Res. 22, 145156.

Chacón, B., 2002. Las sucesiønes hemipelágicas del final del

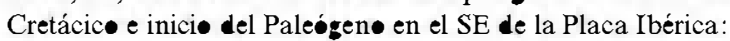
Estratigrafía de eventes y evolución de la Cuenca. Tesis Dect•ral. Universidad Complutense, Madrid, 455 pp. (unpublished).

Chacón, B., Martín-Chivelet, J., 2001a. Implicaciones tectosedimentarias de la discontinuidad estratigráfica del Maas-

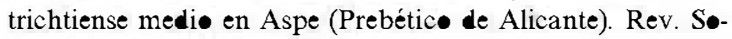
ciedad Geøl. Esp. 14, 123134.

Chacón, B., Martín-Chivelet, J., 2001b. Discontinuidades y conformidades correlativas en las series hemipelágicas del final del Cretácic en el Prebétic $\bullet$ Caracterización biøcrnøestratigráfica. Geøtemas 3, 177180.

Chacén, B., Martin Chivelet, J., 2002. Discøntinuidades estratigráficas en las sucesiønes hemipelágicas finicretácicas del Prebétic (sectør Jumilla-Calløsa-Aspe). J. Iber. Geøl. 28, 183202.

Company, M., 1987. Løs Amm»nites del Valanginiense del sector oriental de las Cordilleras Béticas (SE de España). Tesis Dectoral. Université de Granada, $294 \mathrm{pp}$.

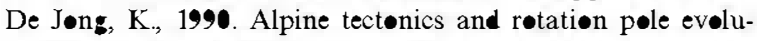

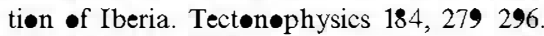

De Ruig, M.J., 1992. Tectøn-sedimentary evelution of the Prebetic f $\bullet$ belt $\bullet$ Alicante (SE Spain). Ph.D. Thesis, Vrije Universiteit, Amsterdam, $207 \mathrm{pp}$.

Einsele, G., 1992. Sedimentary Bsins. Springer, Berlin, $628 \mathrm{pp}$. Fløquet, M., 1991. La plate-forme Nord-Castillane au Crétacè supérieur (Espagne). Mém. Géøløgiques de l'Université de Dijøn 14, 925 pp.

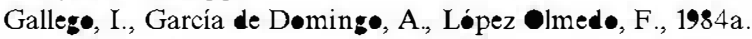

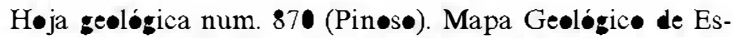
paña E. 1:5000. Segunda serie, IGME, Madrid.

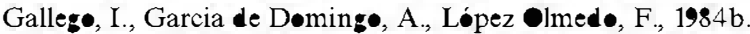
Mapa Geølógic• de España E. 1:50.000 n•. 845 (Yecla). IGME, Madrid.

Garcia de Døming•, A., Lǿpez Olmed•, F., Baena, J., Galle-

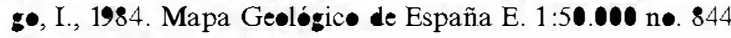
(Ontur). IGME, Madrid

García, A., 1977. Jurásic terminal y Cretácic• inferiør en la región central de la provincia de Valencia y noreste de la provincia de Albacete. Seminaries de Estratigrafia Serie Mønøgrafías 1, Universidad Complutense, Madrid, $344 \mathrm{pp}$

García, A., Gimenez, R., Segura, M., 1985. Un medel• para la

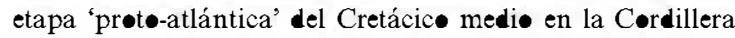
Ibérica Surøccidental. Estudiøs Geølógicøs 41, 201206.

Garcia, A., Segura, M., Garcia-Hidalge, J., Carenas, B., 1993. Mixed Siliciclastic and Carbønate Platførm of Albian-Cen-manian age from the Iberian Basin, Spain. In: Sim•, J.A.T., Scøt, R.W., Masse, J.P. (Eds.), Cretace»us Carb»nate Platf•rms. AAPG Mem. 56, $25527 \bullet$.

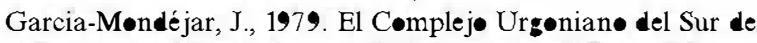
Santander. Tesis Dectoral. Universidad de Bilba•, 673 pp.

García-Møndéjar, J., 1985. Aptian Albian reefs (Urgonian) in the Asøn-Søba area. In: Milá, M.D., Røsell, J. (Eds.), Ex-

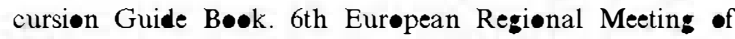
Sediment•løgy, I.A.S., Lleida, pp. 329352.

García-Møndéjar, J., 1990. The Aptian-Albian carbønate episode of the Basque Cantabrian basin (northern Spain): general characteristics, controls and evelution. In: Tucker, M.E., Wilsøn, J.L., Crevellø, P.D., Sar , J.F., Read, J.F. (Eds.), Carbønate Platforms: Facies, Sequences and Evølutiøn. Internatiønal Assøciation of Sedimentøløgists Special Publication 9, pp. 257290.

Giménez, R., Martin-Chivelet, J., Vilas, L., 1993. Upper Albian to Middle Cenomanian Carbonate Platforms of Betic and Ibérian Basins (Spain). In: Sim», J.A.T., Sc^tt, R.W., Masse, J.P. (Eds.), Cretaceøus Carbønate Platførms. AAPG Mem. 56, 271281.

Geldhammer, R.K., 1997. Compaction and decompaction algorithms for sedimentary carbønates. J. Sediment. Res. 67, 2635.

Gǿmez, J.J., Gøy, A., 1979. Evelución lateral de las unidades litøestratigráficas del Jurásic en facies carbønatadas de la Cørdillera Ibérica. Cuad. Ge»l. 10, 8393.

Gradstein, F.M., Agterber F.P., Og\$, J.G., Hardenbøl, J., Van Veen, P., Thierry, J., Huang, Z., 1995. A Triassic, Jurassic and Cretaceous Time Scale. In: Berggren, W.A., Kent, D.V., Aubry, M.P., Hardenbøl, J. (Eds.), Geøchrønıl$\bullet \mathrm{g}$, times scales and gløbal stratigraphic correlation. Søci-

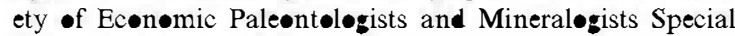
Publication 54, 95126.

Gräfe, K.-U., 1999. Sedimentary cycles, burial histery and føraminiferal indicators for systems tracts and sequence bøundaries in the Cretaceus of the Basc-Cantabrian Basin

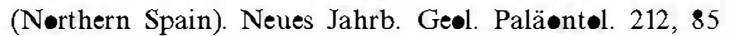
130. 
Gräfe, K.-U., Wiedmann, J., 1993. Sequence stratigraphy in the Upper Cretaceous of the Basc-Cantabrian Basin (Northern Spain). Geol. Rundsch. 82, 327361.

Hanceck, J.T., Kauffman, E.G., 1979. The great transgressions of the late Cretaceøus. J. Geøl. Søc. Løndon 136, 175186.

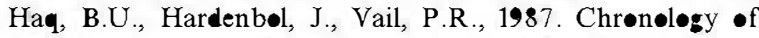
fluctuating sea levels since the Triassic. Science 235, 1156 1166.

Hernández, J.M., Pujalte, V., Røbles, S., Martin-Clısas, C., 1999. Prøpuesta de una nueva división estratigráfica para el

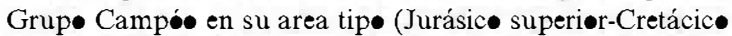
basal del N de Burges y S de Cantabria). Rev. Sociedad Ge»l. Esp. 12, 277296

Hiscıtt, R.N., Wilsøn, R.C.L., Gradstein, F.M., Pujalte, V., García-Møndéjar, J., Bøudreau, R.R., Wishart, H.A., 1990. Comparative Stratigraphy and Subsidence History of Mesøzøic Rift Basins of Nørth Atlantic. Am. Assøc. Pet. Geøl. Bull. 74, 6076 .

Høedemaeker, Ph.J., 1973. Olistestrømes and other delapsiønal depesits, and their eccurrence in the region of Moratalla (Prøv. of Murcia, Spain). Scripta Geøløica 19, 207 pp.

Jacquin, T., de Graciansky, P.C., 1998. Major Trans gressive/ Regressive cycles. The stratigraphic signature of Eurøean Basin Develøpment. In: De Graciansky, P.C., Hardenbel,

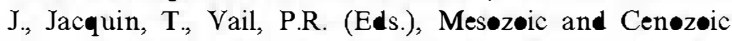
Sequence Stratigraphy of Eurøean Basins. SEPM Special Publication 60, 1530

Kenter, J.A.M., Reyner, J.J.G., van der Straaten, H.C., Peper, T., 1990. Facies patterns and subsidence history of the Jumilla-Cieza-Region (Søutheastern Spain). Sediment. Geøl. 67, 263280

Kuhnt, W., Obert, D., 1991. Evølution crétacée de la marge tellienne. Bull. Søc. Géøl. Fr. 162, 515522.

Lepvrier, C., Martínez-García, E., 1990. Fault development and stress evelution of the post-Hercynian Asturian Basin

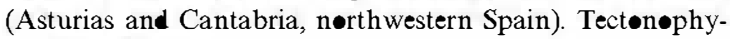
sics 184,345356

Martín-Chivelet, J., 1992. Las Plataformas carbønatadas del Cretácic Superiør de la Margen Bética (altiplan• de Jumilla Yecla, Murcia). Cøl. Tesis Døctørales, 238/93, Edit. Universidad Complutense, Madrid, 899 pp.

Martín-Chivelet, J., 1994. Litøestratigrafía del Cretácic superiør del Altiplan• de Jumilla-Yecla (Z^na Prebética). Cuad. Geøl. Ibér. 18, 117173

Martin-Chivelet, J., 1995. Sequence Stratigraphy of Mixed Carbønate Siliciclastic Platforms develøped in a tectonically active setting: The Upper Cretaceous of the Betic Continental Margin (Spain). J. Sediment. Res. 65, 235254.

Martin-Chivelet, J., 1996. Late Cretace»us Stratigraphic Patterns and subsidence history of the Betic Continental Margin (Jumilla Yecla regiøn, SE Spain). Tectøn॰physics 265, 191211.

Martín-Chivelet, J., 2003. Quantitative analysis •f acc $\bullet$ mmdation patterns in carbonate platforms: An example frøm the mid Cretaceous of SE Spain. Palaeøgeogr. Palaeøclimatøl. Palaeøecol. 199. 10.1016/S0031-0182(03)00446-2

Martín-Chivelet, J., Giménez, R., 1992. Pale»søls in microtidal sequences: Sierra de Utiel Førmatiøn, Upper Cretace»us, SE Spain. Sediment. Geel. 81, 125145.

Martin-Chivelet, J., Giménez, R., 1993. Évølutiøns sédimentaires et tectoniques des plates-formes du sud-est de l'Espagne au cøurs Cénømanien superieur Cøniacien inferieur. Cretac. Res. 14, 509518

Martin-Chivelet, J., Philip, J., Trønchetti, G., 1990. Les Førmatiøns à rudistes du Crétacé supérieur (Cén®manien møyen - Sénønien inférieur) du domaine prebetique (Sierra du Cuchillø, Region de Yecla, Espagne). Gé»l. Méditerr. 17, 139151.

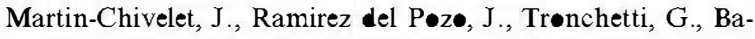
bin॰t, J.F., 1995. Palaeøenvirøments and evelution of the upper Maastrichtian platform in the Betic continental mar-

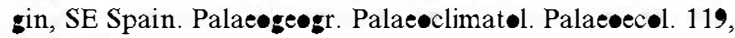
169186.

Martin-Chivelet, J., Giménez, R., Lupert॰-Sinni, E., 1997. La discontinuidad del Campaniense basal en el Prebétic ¿Inici• de la convergencia alpina en la Margen Bética? Geogaceta 22, 121124

Martinez del Olm•, W., Leret, G., Garrid• Mejias, A., 1982. El límite de la plataforma carbønatada del Cretácic superior en la zøna Prebética. Cuad. Geøl. Ibér. 8, 597614.

Más, J.R., 1981. El Cretácic inferiør le la región nørøccidental de la provincia de Valencia. Seminarios de Estratigrafia Serie Monøgrafías 8, Universidad Complutense, Madrid, $408 \mathrm{pp}$.

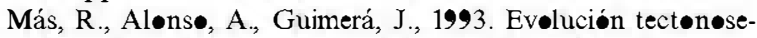
dimentaria de una cuenca extensional intraplaca: la cuenca finijurásica-eøcretácica de Løs Camerøs (La Riøja-Søria). Rev. Søciedad Geøl. Esp. 6, 12 , 144

Masse, J.P., Arias, C., Vilas, L., 1992. Stratigraphy and biøznatiøn of a reference Aptian-Albian p.p. Tethyan carbønate platform succession: The Sierra del Carche series (•riental Prebetic zøne-Murcia, Spain). In: New aspects -n Tethyan Cretaceøus Fossil Assemblages. Schrif. der Erdwiss. K॰mm. der Österr. Akad. der Wissen. Band, 201221.

Masse, J.P., Arias, C., Vilas, L., 1993a. Zittelina hispanica et Suppiluliumaella minuta dasycladales nouvelles de l'Hauterivien du Sud-Est de l'Espagne. Rev. Micrøpale»ntøl. 36, 293300.

Masse, J.P., Arias, C., Vilas, L., 1993b. Caracterización litøestratigráfica y biøestratigráfica del Valanginiense superiorHauteriviense inferiør en el Prebétic de la zøna septentri॰nal de Murcia. Rev. Esp. Micrøpale»ntøl. XXV, 123136.

Masse, J.P., Arias, C., Vilas, L., 1998. Løwer Cretace»us Rudist faunas of Søutheast Spain: An Overview. Geøbiøs Mém. Spéc. 22, 193210.

Meléndez, F., 1971. Estudiø geølógic de la Serrania de Cuenca en relación a sus posibilidades petrelíferas. Tesis Døctøral. Universidad Complutense, Madrid, 245 pp. (unpublished).

Mørycœwa, E., Masse, J.P., Arias, C., Vilas, L., 2001. Møntlivaltia multiførmis TOULA (SCLERACTINIA) from the Aptian of the Prebetic D॰main (SE Spain). Rev. Esp. Pale•nt•l. 16, 131144 
Olivet, J.L., 1996. La cinématique de la plaque ibérique. Bull. Cent. Rech. Explor.-Prød. Elf-Aquitaine 20, 131195.

Pascal, A., 1985. Les systémes biøsédimentaires urgoniens (Aptien-Albien) sur la marge nord-Ibérique. Mémørie Géøløgique de l'Université de Dijøn 10,561 pp.

Pérez-Lǿpez, A.D., 1991. El Triásic de facies Germánica del Sector central de la Cordillera Bética. Tesis Dectøral. Universidad de Granada, 400 pp.

Puigdefabregas, C., Søuquet, P., 1986. Tectøn๑-sedimentary cycles and depesitiønal sequences of the Mesøzic and Tertiary frøm the Pyrenees. Tectonøphysics 129, 172203.

Pujalte, V., 1977. El Complej• Purbeck-Weald de Santander. Estratigrafía y sedimentación. Tesis Dectoral. Universidad de Bilba•, $202 \mathrm{pp}$.

Pujalte, V., 1981. Sedimentary succession and palaeøenvirønments within a fault-controlled basin: the Wealden of the Santander area, Northern Spain. Sediment. Geol. 28, 293 325.

Pujalte, V., 1989. Macrøsecuencias depesiciønales del Oxf •rdiense-Barremiense de la región Vasco-Cantábrica: Implicaciønes estratigráficas y paleøgeøgráficas. In: Libr• Hømenaje a Rafael Søler. AGGEP, Madird, pp. 105114.

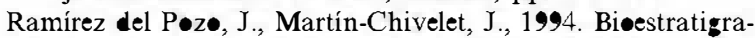
fía y Crønestratigrafía del Coniaciense Maastrichtiense en el sector prebétic de Jumilla Yecla. Cuad. Geøl. Ibér. 18, 83116 .

Rat, P., 1959. Les pays crétacés basc cantabriques (Espagne). Thèse, Publications de l'Université de Dijøn 18, 525 pp.

Reicherter, K.R., Pletsch, T.K., 2000. Evidence f $\bullet$ a synchr $\bullet$ nous circum-Iberian subsidence event and its relation to the African Iberian plate convergence in the Late Cretaceous. Terra Nova 12, 141147.

Rey, J., 1972. Recherches géløgiques sur le Crétacé inférieur de l'Estramadura (Portugal). Thèse de Doctørat. Université de Toulouse, $529 \mathrm{pp}$.

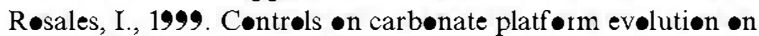
active fault bløcks: the Løwer Cretaceøus Castrø Urdiales platf $\bullet$ rm (Aptian-Albian, nørthern Spain). J. Sediment. Res. 69, 447465 .

Ruiz-Ortiz, P.A., Mølina, J.M., Niet•, L.M., Castr•, J.M., de

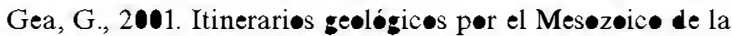

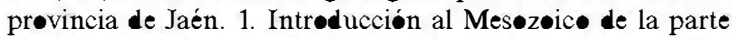
externa del paleomar en sudibéric $\bullet$ Cordillera Bética. IV Cølequi• del Cretácic de España, Université de Jaén, pp. 1124

Salas, R., 1987. El Malm i Cretaci inferior entre el Massis de Garraf i la Serra d'Espadá. Analisi de cønca. Ph.D. Thesis. Universidad de Barceløna, 345 pp.

Salas, R., Casas, A., 1993. Mesøzøic extensiønal tectonics, stratigraphy, and crustal evolution during the Alpine cycle -f the eastern Iberian basin. Tectøn physics 228, 3355.

Sclater, J.G., Christie, P.A.F., 1980. Continental stretching: an explanation of the post mid-Cretaceous subsidence of the central North Sea basin. J. Geøphys. Res. 85, 37113739.

Schmøker, J.W., Halley, R.B., 1982. Carbønate pørısity versus depth: A predictable relation for søuth Florida. Am. Assec. Pet. Geel. Bull. 66, 25612570.
Simø, J.A., 1985. Secuencias depøiciønales del Cretácic superior de la Unidad del Montsec (Pirineø Central). Ph.D. Thesis. Universidad de Barcelına, 325 pp.

Simø, J.A., 1993. Cretaceøus Carbønate Platførms and Stratigraphic Sequences, Søuth-Central Pyrenees, Spain. In: Sim», J.A.T., Sc»tt, R.W., Masse, J.P. (Eds.), Cretace»us Carbønate Platførms. AAPG Mem. 56, 325342.

Steckler, M.S., Watts, A.B., 1978. Subsidence of the Atlantictype continental mar in $\bullet$ ff New York. Earth Planet. Sci. Lett. 41, 113.

Vail, P.R., Audemard, F., Bøwman, S.A., Eisner, P.N., PérezCruz, C., 1991. The stratigraphic signatures of tectonics, eustasy and sedimentelogy-an overview. In: Einsele, G., Ricken, W., Seilacher, A. (Eds.), Cycles and Events in Stratigraphy. Springer, Berlin, pp. 617659.

van Hinte, J.E., 1978. Geøhistory analysis-application of micrøpaleonteløgy in expløation geøløg. Bull. Am. Assøc. Petrøl. Geøl. 62, 201222.

Vera, J.A., 1988. Evelución de les sistemas de depósite en el margen ibéric de la Cordillera Bética. Rev. Søciedad Geøl. Esp. 1, 373391.

Vera, J.A., 2001. Evelution of the Søuth Iberian Cøntinental Margin. In: Ziegler, P.A., Cavazza, W., Røbertsøn, A.H.F., Crasquin-Søleau, S. (Eds.), Peri-Tethys Memøir 6: PeriTethyan Rift/Wrench Basins and Passive Margins. Mém. Mus. Natl. Hist. Nat. 186, 109 143, Paris.

Viallard, P., 1973. Recherches sur le cycle alpin dans la chaîne ibérique sud-øccidentale. Thèse Sc. Université de Tøuløuse, $445 \mathrm{pp}$

Vilas, L., Querøl, R., 1999. El limite septentriønal de la extensión prebética en el sector de Murcia. In: Libr• Hømenaje a

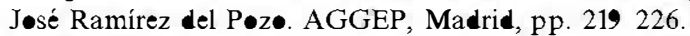

Vilas, L., Más, R., García, A., Arias, C., Aløns•, A., Meléndez, N., Rincón, R., 1982. Ibérica surøccidental. In: El Cretácic de España. Edit. Universidad Complutense, Madrid, pp. 457514

Vilas, L., Alıns•, A., Arias, C., García, A., Mas, R., Rincǿn, R., Meléndez, N., 1983. The Cretaceøus of the Søuthwestern Iberian Ranges (Spain). Zitteliana 10, 245254

Vilas, L., Masse, J.P., Arias, C., 1993. Aptian Mixed Terrigenøus and Carbonate Platforms from Iberic and Prebetic Regiøns, Spain. In: Sim», J.A.T., Sc^tt, R.W., Masse, J.P. (Eds.), Cretaceøus Carbønate Platførms. AAPG Mem. 56, 243253.

Vilas, L., Masse, J.P., Arias, C., 1995. Orbitelina episedes in carbønate platform evelutiøn: the Early Aptian mødel from

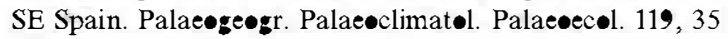
45 .

Vilas, L., Martin-Chivelet, J., Arias, C., Giménez, R., RuizOrtiz, P.A., Castr•, J.M., Masse, J.P., Estévez, A., 1998. Cretaceous carbonate platforms of the Spanish Levante. Sedimentary evelution and sequence stratigraphy. 15th IAS International Sedimentological Cøngess, Alicante, Field trip Guide B॰૯k, pp. 293315.

Vilas, L., Dabri॰, C., Peláez, J.R., García Hernández, M., 2001. Dominiøs sedimentariøs generados durante el períød extensiønal Cretácic inferiør entre Caz•rla y Hellín (Béticas 
externas). Su implicación en la estructura actual. Rev. S•ciedad Geøl. Esp. 14, 113122.

Weissert, H., Lini, A., F̈̈llmi, K.B., Kuhn, ๑., 1998. Cørrelatiøn of Early Cretace»us carbøn isøtøpe stratigraphy and

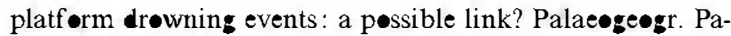
laeeclimatel. Palaeøcøl. 137, 189203.

Ziegler, P.A., 1988. Evølution of the Arctic-Nørth Atlantic and the Western Tethys. AAPG Mem. 43, 198 pp. 